\title{
Spatial assessment of the distribution and potential of bioenergy resources in Kazakhstan
}

\author{
Asima Koshim $^{1}$, Marat Karatayev ${ }^{2,3}$, Michèle L. Clarke ${ }^{2,4}$, and William Nock ${ }^{5}$ \\ ${ }^{1}$ Department of Cartography, Al-Farabi Kazakh National University, Al-Farabi Avenue, 71, 050040, Almaty, Kazakhstan \\ ${ }^{2}$ Energy Technologies Research Institute, The University of Nottingham, Nottingham, NG8 1BB, UK \\ ${ }^{3}$ The Water-Energy-Food Nexus Partnership Program, ETH Zurich, Rämistrasse 101, 8092 Zurich, Switzerland \\ ${ }^{4}$ School of Geography, The University of Nottingham, Nottingham, University Park, NG7 2RD, UK \\ ${ }^{5}$ Department of Chemical Engineering and Biotechnology, University of Cambridge, Cambridge, CB2 1TN, UK
}

Correspondence: Asima Koshim (asima.koshim@kaznu.kz)

Received: 23 May 2018 - Revised: 9 August 2018 - Accepted: 13 August 2018 - Published: 28 August 2018

\begin{abstract}
Kazakhstan is naturally rich in fossil fuels and its economy is strongly linked to oil and gas exports. Significant coal reserves have led to an energy mix that is dominated by aging and polluting thermal power plants. Yet Kazakhstan comprises mainly grassland steppe where agriculture and livestock pastoralism dominate offering the potential for cleaner, renewable energy production from a range of agricultural and forestry wastes. Here we analyse the spatial distribution and bioenergy generation potential of different feedstocks using an ArcGIS platform and demonstrate a significant opportunity for a range of bioenergy technologies. We recommend a number of policy interventions to enable Kazakhstan to make a transition to cleaner, more accessible and locally generated supply which is also sustainable and provide a waste management solution.
\end{abstract}

\section{Introduction}

Kazakhstan is a large steppe country located in Central Asia. It is surrounded by Turkmenistan, Uzbekistan, and Kyrgyzstan to the south, Russia to the north, China to the east, and is bounded to the west by the Caspian Sea. The country has a total land area of 2.7 million $\mathrm{km}^{2}$, sub-divided into fourteen administrative provinces (Fig. 1a), each governed from a local centre, usually the largest local city, which is called the capital of that province. Generally, the climate of Kazakhstan is extreme continental with average temperature between -4 and $-19^{\circ} \mathrm{C}$ in January and between +19 and $+26^{\circ} \mathrm{C}$ in July. The country is almost entirely covered by steppe and desert with brown and grey-brown soils; the northern area of Kazakhstan is the wettest region, where precipitation exceeds $300 \mathrm{~mm} \mathrm{yr}^{-1}$ (Fig. 1b), mainly because of afternoon thunderstorms that occur in summer, while in the centre and south, precipitation is around $150-200 \mathrm{~mm} \mathrm{yr}^{-1}$ (KIG, 2013). According to Kazakhstan's Agency of Statistics, the country has an estimated population of around 17.8 million (KAS, 2016) and $60 \%$ of people live in cities (Nyussupova and Kalimurzina, 2016). The energy sector plays a major role in Kazakhstan's economic development. The country has abundant reserves of fossil fuel (oil, gas and coal) and proven gas reserves estimated at about 3.8 trillion $\mathrm{m}^{3}$ (EIA, 2017). Natural gas and clean energy technologies have the potential to contribute to reducing the country's carbon footprint (Kerimray et al., 2018); there are plans to build additional gas infrastructure that will bring natural gas to Kazakhstan's capital of Astana, and large cities in the North and Central Kazakhstan (MoE, 2018). Gas grid connectivity is expected to reach $56 \%$ of the population by 2030 , compared to $47.3 \%$ currently (MoE, 2018). The potential oil resources in Kazakhstan are estimated to be over 30 billion barrels and Kazakhstan is a strongly export dominated economy with between $75 \%-80 \%$ of its total oil production exported overseas. In 2016 , oil production was around 79.4 Mt against a consumption of 14.6 (EIA, 2017). Kazakhstan has also significant coal reserves, especially in central part of Kazakhstan. Its total recoverable coal reserves were estimated in 2015 at around 176.7 million short tons (EIA, 2017). Despite the abundance of oil and gas, the country's power generation has been dominated by coal. By the end of 2016, coal-fired thermal power 

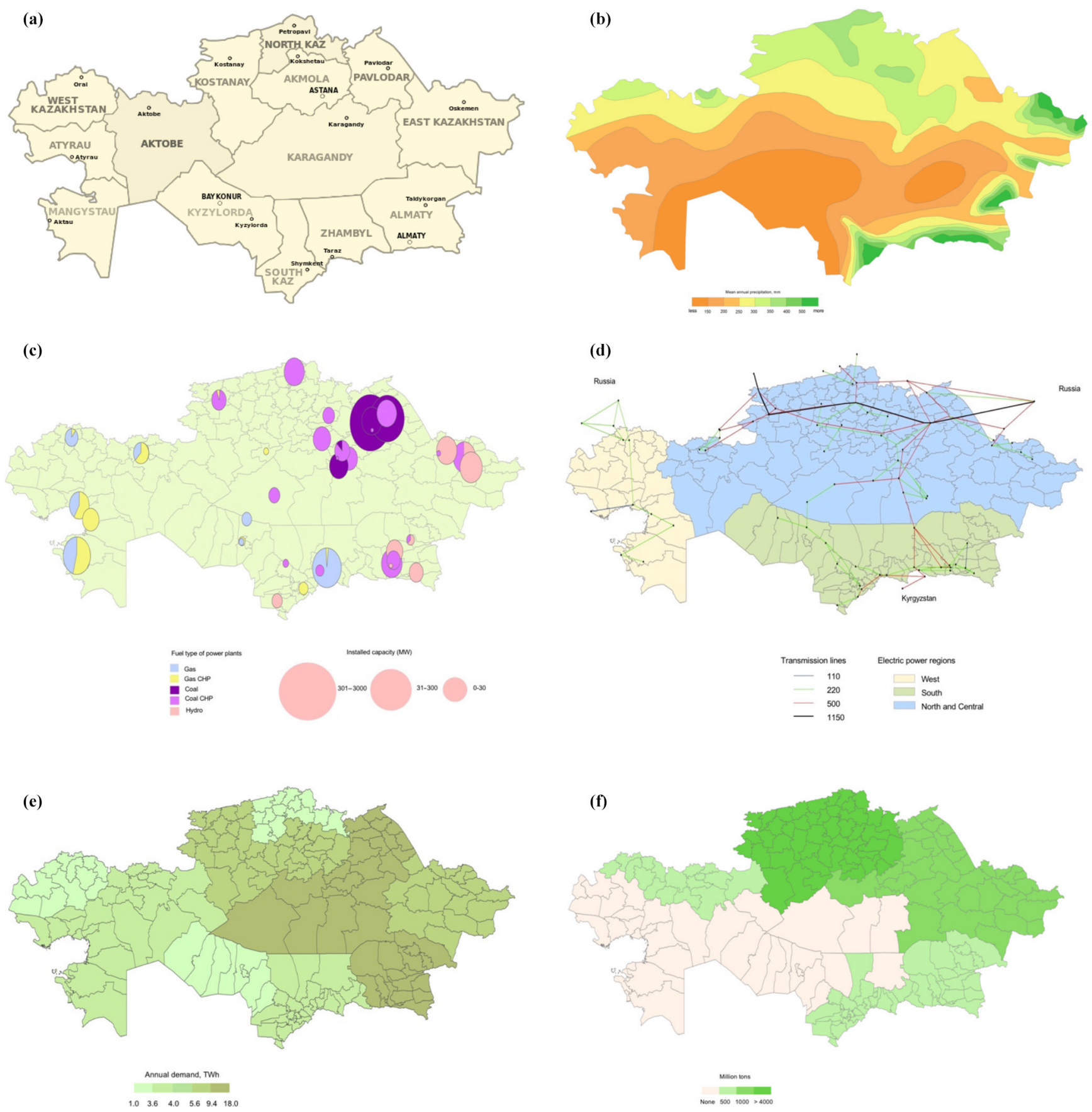

Figure 1. (a) Administrative provinces of Kazakhstan; (b) mean annual precipitation; (c) electricity capacity generation by fuel type; (d) electric power zones; (e) annual energy demand by regions; (f) major areas of wheat production.

in Kazakhstan comprised $75 \%(15 \mathrm{GW})$ of the total installed capacity and contributed $80 \%$ ( $82.4 \mathrm{TWh}$ ) of total generated electrical energy, mainly concentrated close to the coal fields in the North of Kazakhstan (Fig. 1c). The North and Central regions of Karaganda, Pavlodar, Akmola, Kostanay, Aktobe, East Kazakhstani provinces have a $220-500-1150 \mathrm{kV}$ electric grid that is connected to Russia's electricity system (Fig. 1d) and these provinces have higher electricity con- sumption than in the West and South (Fig. 1e) (KEGOC, 2016). Coal is expected to play a dominant role in national energy balance at least for the next 30-40 years (Kazenergy, 2017). The domination of coal in Kazakhstan's current energy balance coupled with its aging plant and unequal spatial distribution networks (including electricity production) contributes both to regional energy price inequalities (Assembayeva et al., 2018) and to ongoing serious environmental 
damage (Kerimray et al., 2017). Coal power stations are responsible for almost $80 \%$ of the country's carbon emissions (ICSD, 2016). The quality of Kazakhstani coal is relatively poor, with a high ash content of between $50 \%$ to $65 \%$ (EIA, 2017). Given current and projected future coal use in Kazakhstan, and the need to cut emissions, biomass co-firing in coal power stations is regarded as a promising option which could enable Kazakhstan to cut its carbon emissions and provide an improved sustainable energy supply.

Currently, there are three co-firing technologies widely used in power plants: direct co-firing, indirect co-firing, and parallel co-firing. In direct co-firing, biomass is directly fed into the furnace along with base fossil fuel (e.g. coal). Indirect co-firing installs a separate gasifier to convert the solid biomass into a fuel gas (syngas). Parallel co-firing involves the installation of a completely separate external biomassfired boiler in order to produce steam used to generate electricity in the coal-fired power plant. Biomass co-firing does not require significant capital investment and has the advantage of being able to use existing fossil fuel power plants infrastructure (Roni et al., 2017). Biomass co-firing can replace between $20 \%-50 \%$ of coal and reduces carbon dioxide emission from the power plant; the amount of other pollutants released will depend on the characteristics of the biomass feedstock (Lempp, 2013).

Kazakhstan has various biomass resources including forest wood and agricultural residues. While the spatial distribution and potential of solar and wind energy has been previously demonstrated (UNDP, 2015, 2018; Terehovics et al., 2017; Ahmad et al., 2017) to date there has not been any analysis of bioenergy feedstocks for potential use in energy generation in Kazakhstan. Here we present the available biomass resources (crop residues, the production of livestock residues and forest residues) and then evaluate for the first time the total amount and the spatial distribution of the crop residue availability for energy generation. This type of assessment is needed by policy makers and local governments in their efforts to establish medium- and long-term planning for the development of biomass and biogas resources, and for enterprises and planners to arrange for the development and implementation of projects related to biomass resources.

\section{Available bioenergy resources}

\subsection{Crop residues}

In 2016, Kazakhstan produced nearly 27 million tons of crops (KAS, 2017). The UN FAO estimated that the maximum crop production from Kazakhstan in good years exceeds 35-40 million tons (FAO, 2016). Wheat is the main crop in Kazakhstan, producing around 14-16 million tons of grain annually (KAS, 2017). Around $75 \%-80 \%$ of Kazakhstan wheat production occurs in North Kazakhstan including Akmola, Kostanay, and Northern Kazakhstani provinces, with a small amount being produced in the south (Fig. 1f). The east and south of Kazakhstan are area of fibre and nongrain crop production includes cotton, flax, sugar beet, and tobacco (Fig. 2a). The south, east and central Kazakhstan is also major area of fodder crop production including barley, oil seed rape, grass, maize, millet, soya beans and oats (Fig. 2b). According to our data, from 2004 to 2016, the total plant based agricultural produce (including grain, cobs, seeds, straw, husks, chaff) has been estimated to be around 16.4 $\mathrm{Mt} \mathrm{yr}^{-1}$. The agricultural residue available for bioenergy production (straw, cobs, husks) is about $8.2 \mathrm{Mt} \mathrm{yr}^{-1}$. The principle locations of agricultural wastes which can be converted to energy production are shown in Fig. 2c. The highest percentage of residues is found in the North regions of Akmola, Kostanay, and Northern Kazakhstani provinces, followed by the East and South regions, each containing more than 1.2 million tons of residues per year available for bioenergy. Approximately $7 \%$ of this is used as livestock fodder and bedding; the rest is buried (KAS, 2017), burned or ploughed in.

\subsection{Animal wastes}

Organic-rich animal wastes are increasingly used for bioenergy generation in anaerobic digestion plants which produce biogas (principally methane and carbon dioxide) and digestate residue which can be used as an agricultural fertiliser. The animal waste residues produced in Kazakhstan depends on the animal type, size, and population density for each location. Livestock production in Kazakhstan contributes to rangeland management and for example the total cattle herd was estimated at about 6.204 million head in 2016 (KAS, 2017). For energy production, animals need to be housed for some of the year in order to make residue collection cost effective. Livestock are spatially distributed driven by climatic conditions which controls grass cover and tend to be found principally in the eastern, northern and southern provinces of Kazakhstan, while the west and central regions fewer livestock numbers (Fig. 2d). For cattle manure, Kazakhstan's annual production is about 45 million tons, mostly from the South-Eastern region of Kazakhstan followed by North region and Central region (KAS, 2017).

\subsection{Forestry}

In Kazakhstan, the forested area occupies around $4.7 \%$ (over 12 million ha) of the land area of the country, and of this about $40 \%$ is estimated to host productive forestry (FAO, 2016). The total standing timber stock is 375.7 million $\mathrm{m}^{3}$ (KAS, 2017) and forests produce between 0.8 and 1.0 million $\mathrm{m}^{3}$ of timber annually (KAS, 2017). The region with largest forest cover is in Kyzylorda in mountainous south Kazakhstan and woodlands are also prevalent in the south-eastern regions, though not all of these will be suitable for forestry (Fig. 2e). According to Kazakhstan's 
(a)
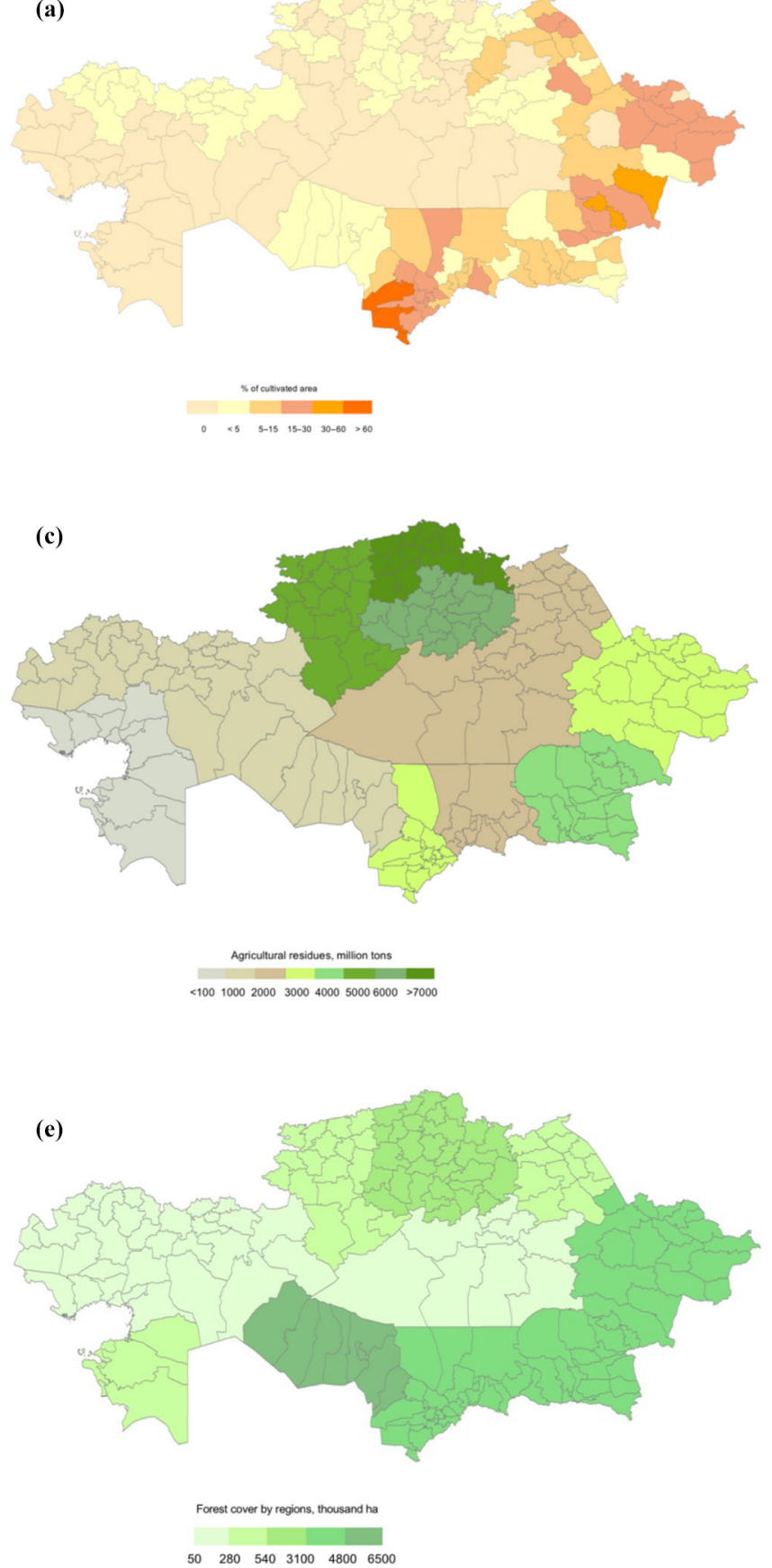
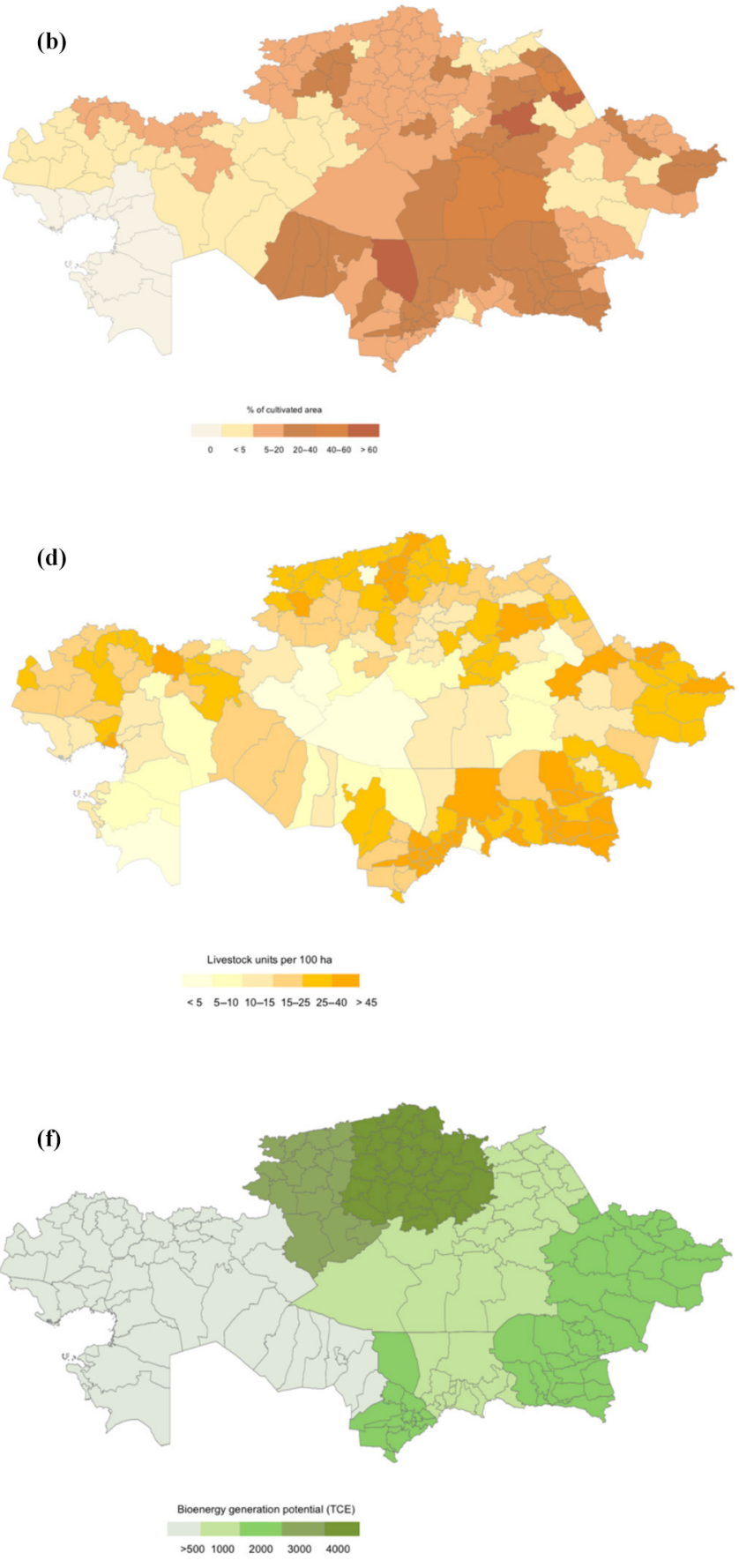

Figure 2. (a) Areas of fibre and non-grain crop production; (b) major areas of fodder crops production; (c) availability of crop residues; (d) number of livestock per 100 ha; (e) forest cover in Kazakhstan; (f) energy generation potential from crop residues.

Agency of Statistics, the largest productive standing timber stock is concentrated in the eastern region of Kazakhstan (44.5\%), Kyzylorda in the south (10.5\%), Akmola (11.4\%) and Pavlodar provinces $(7.1 \%)$ in the north. These locations have the potential for biomass co-firing through creative of wood chips and wood pellets.

\section{Bioenergy generation potential}

\subsection{Estimation and mapping bioenergy resources}

Due to issues with the availability of data, this paper focuses on crop residues. Theoretical energy potential from 
crop residues is analysed via an ArcGIS platform, according to the following steps:

1. Selection of agricultural crops

The crops considered in this study whose residues that have potential to be used feedstocks for bioenergy production include wheat, rice, oil-bearing crops (e.g. oilseed rape), cotton, sugar crops, tubers, and beans. Data on production by province from 2004 to 2016 was obtained from Kazakhstan's Agency of Statistics (KAS, 2017).

2. Calculation of total yield of crop residues

Total values of crop residues were estimated using the following mathematical model:

$\operatorname{CRs}(i, j)=\sum_{i=1}^{n} \operatorname{CBA}(i, j) \times \operatorname{RPR}(i, j)$

where: $\operatorname{CRs}(i, j)$ is total yield of $i$ crop residues at $j$ province, ton; CBA $(i, j)$ is total yield of $i$ crop production at $j$ province, ton; $\operatorname{RPR}(i, j)$ is the residue production ratio of $i$ crop residues at $j$ province;

The crop-to-residues ratios were derived from FAO's Bioenergy and Food Security Rapid Appraisal Tool (FAO, 2017).

3. Calculation of bioenergy potential

Bioenergy potential from crop residue biomass was estimated using the following mathematical model:

$E(i, j)=\sum_{i=1}^{n} \operatorname{CRs}(i, j) \times \operatorname{TV}(i, j)$

where: $E(i, j)$ is bioenergy potential of $i$ crops at $j$ province, $\mathrm{MJ}$; CRs $(i, j)$ is total yield of $i$ crop residues at $j$ province, ton; $\operatorname{TV}(i, j)$ is thermal value of $i$ crop residues, $\mathrm{MJ} \mathrm{t}^{-1}$.

Thermal values of residues were taken from FAO's Bioenergy and Food Security Rapid Appraisal Tool (FAO, 2017).

Both mathematical models were used in previous studies to assess bioenergy potential, for example, in China (Jiang et al., 2012), Russia (Namsaraev et al., 2018), India (Hiloidhari et al., 2014) and Egypt (Kamel et al., 2018).

4. Mapping the results

An ArcGIS approach has been adopted in this study to map the potential regions for bioenergy production across Kazakhstan. ArcGIS has been used in many bioenergy studies for this purpose including India (Ramachandra and Shruthi, 2007), Northern Europe (Kukk et al., 2011), China (Zhuang et al., 2011; Chang et al., 2014), Mexico (Valdez-Vazquez et al., 2010), Iran (Noorollahi et al., 2015), Zambia (Shane et al., 2016) and Uganda (Twaha et al., 2016).

\subsection{Theoretical bioenergy potential}

Based on net biomass yield from different residues and its conversion efficiency (thermal values of each type of residues), the bioenergy potential in Kazakhstan is estimated at $485.36 \mathrm{MJ}$ (or 16.582 million tons of coal equivalent, with an average of $14.150 \mathrm{Mt} \mathrm{yr}^{-1}$ in the past 12 years) (Table 1 ). This is equivalent to around $30 \%$ of the total current energy consumption of the country. In Kazakhstan, biomass energy resource mainly consists of wheat residues (44\%), produced in the Northern part of Kazakhstan. Consequently, the highest potential for biomass co-firing is found in the northern part of Kazakhstan in Akmola, Kostanay, and other northern provinces (Fig. 2f). The biomass energy potential from wheat residues is found to be $3612.0 \mathrm{Mt} \mathrm{yr}^{-1}$ in Akmola, 3101.4 $\mathrm{Mt} \mathrm{yr}^{-1}$ in Kostanay and 2846.3 $\mathrm{Mt} \mathrm{yr}^{-1}$ other northern provinces. Given that coal-fired power plants are also prevalent in these regions, this demonstrates the great potential for adopting the use of biomass co-firing technologies in this part of Kazakhstan, with concomitant impacts on emissions leading to reduced greenhouse gas release (see Figs. 1c and 2f). The southern part of Kazakhstan (Almaty and Southern Kazakhstanskaya provinces), also shows potential with a maximum of $2105.5 \mathrm{Mt}$ of biomass residues per year.

\subsection{Limiting factors for bioenergy development}

Bioenergy production from agricultural residues is hugely dependent on water availability (including precipitation) and land resources. Kazakhstan is the most water stressed country in the world, according to the Water Stress Index (WSI, 2015). Of the 186 countries studied, Kazakhstan is on the top of the list of 35 most likely countries to experience an interruption to water supply (WSI, 2015). As shown on Fig. 3a, Northern and South-Eastern zones of Kazakhstan have the largest areas with extremely high-water stress. This means that droughts are expected to occur on average every five years in these regions and the present hazard level may increase in the future due to the effects of climate change (Salnikov et al., 2015). Furthermore, Kazakhstan has been experiencing soil erosion and degradation due to salinization, acidification, and contamination by anthropogenic pollution. According to KIG (2013), most of territory of Kazakhstan, 179.9 out of 272.5 million ha ( $66 \%$ of total area) has moderate level of soil degradation and $31.3 \%$ of total irrigated lands are salinized and all degraded arable lands have lost soil organic carbon (humus; Fig. 3b). There are areas with high level of soil degradation across western, northern and south-eastern zones of Kazakhstan which challenges agricultural productivity. 

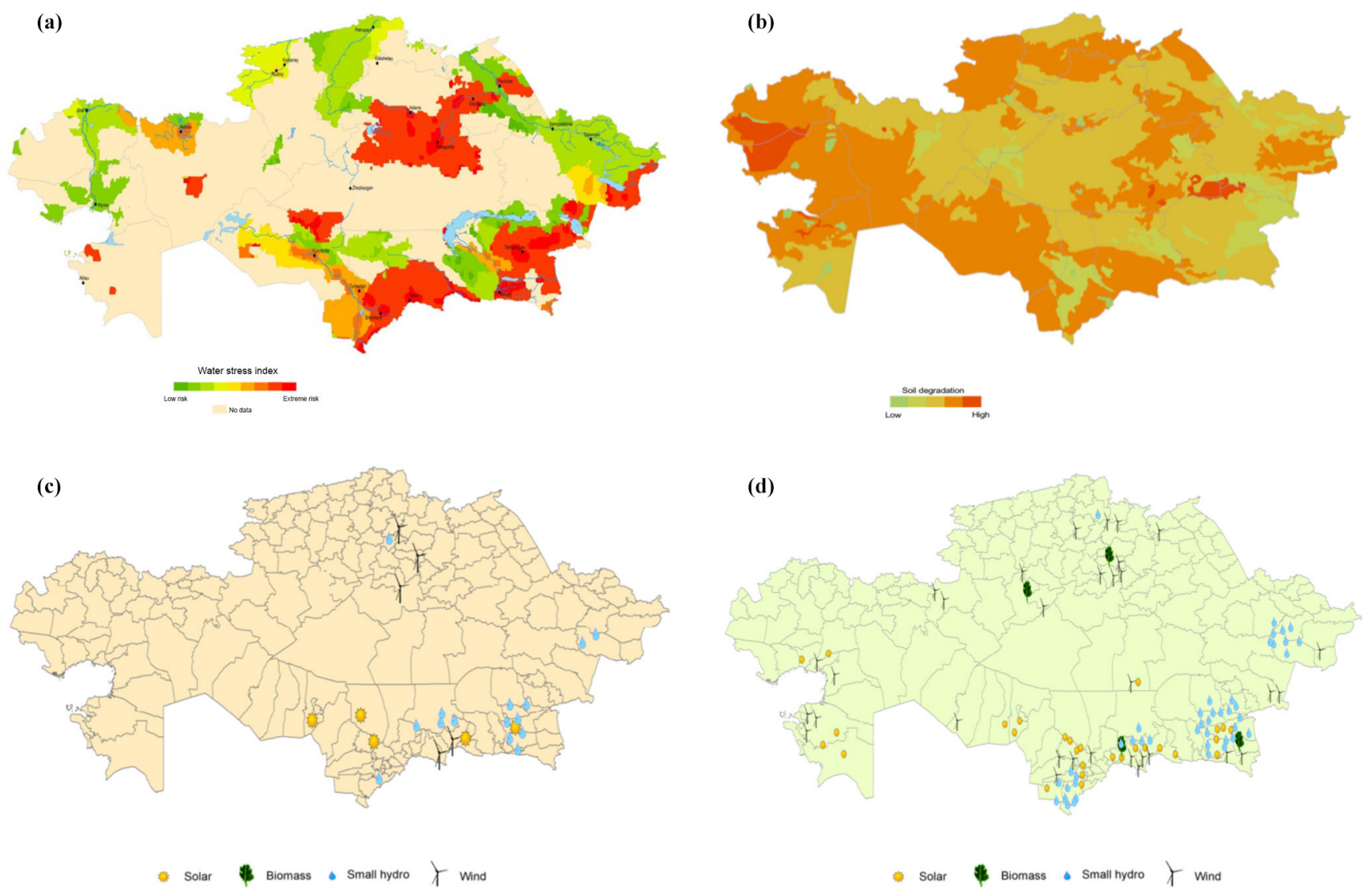

Figure 3. (a) Degree of water stress (WRI, 205); (b) degree of soil degradation (KIG, 2013); (c) current renewable energy projects; (d) future renewable energy projects as a part of Renewable Energy Action Plan for 2012-2030.

\section{Bioenergy policy in Kazakhstan and some recommendations}

To promote the development of renewable energy in Kazakhstan, the government issued the National Green 2050 Economy Concept in 2013 (no. 577 of 30 May 2013), followed by the Law on Green Economy in 2016 (no. 506-V of 28 April 2016) and the Renewable Energy Action Plan for 2012-2030 (Directive no. 068 of 24 February 2017). Kazakhstan has set the target of raising the share of renewable resources in electricity production from $3 \%$ by 2020 to $50 \%$ by 2050 (Karatayev and Clarke, 2016). These targets and government strategies encourage the uptake and commercialisation of biogas, biomass-derived liquid fuels and biomass generated electricity sectors (Karatayev et al., 2017). The National Parliament has approved a Law on the Regulation of Production of Energy from Biomass Resources no. 351-IV and National Tariffs for Energy Produced from Biomass Resources (Directive no. 645 of 12 June 2014). In 2016, the Ministry of Industry and New Technologies proposed four projects of biofuel production in North and South Kazakhstan (Fig. 3c and d). However, the development of a modern bioenergy sector in the country is still limited due to a number of specific barriers that resource-rich countries currently face (Karatayev et al., 2016). The current availability of fossil fuels coupled with insufficient political will have hindered the development of the renewable energy sector in Kazakhstan (Karatayev et al., 2016). Artificially low electricity prices, subsidised up to $60 \%$ by the government, continues to be one of the main drivers of energy policy in Kazakhstan. In order to enable development of the bioenergy industry in Kazakhstan we recommend:

1. Biomass co-firing technologies should be included in national energy targets, programmes and legislation especially given that existing power plants can be easily adapted. The European Union countries adopted the 2020 Energy and Climate Directive (Directive 2009/29/EC) setting three key targets including a $20 \%$ cut in greenhouse gas emissions (from 1990 levels), $20 \%$ of EU energy from renewables and $20 \%$ improvement in energy efficiency. The Directive on Renewable Energy (2001/77/EC) provides the framework for electricity production from biomass and the Biomass Action Plan (2005/628/EC) states that electricity can be generated and co-fired from all types of biomass, by mixing 
Table 1. Annual estimates of bioenergy potential from crop residues.

\begin{tabular}{lrrr}
\hline Crop & $\begin{array}{r}\text { Residue } \\
(\mathrm{Mt})\end{array}$ & $\begin{array}{r}\text { Equivalent } \\
\text { standard coal (Mt) }\end{array}$ & $\begin{array}{r}\text { Energy } \\
\text { potential (MJ) }\end{array}$ \\
\hline 2004 & & & \\
\hline Wheat & 10930.7 & 5465.4 & 159972.2 \\
Oil-bearing crops & 791.6 & 418.8 & 12258.2 \\
Sugar crops & 39.8 & 17.5 & 512.2 \\
Cotton & 1401.3 & 760.9 & 22271.5 \\
Tubers & 2059.3 & 1000.8 & 29293.4 \\
Beans & 2341.8 & 1271.6 & 37219.7 \\
Rice & 1059.7 & 454.6 & 13306.1 \\
Total & 18624.2 & 9389.6 & 274833.1 \\
\hline 2016 & & & \\
Wheat & 16483.9 & 8242.0 & 241243.3 \\
Oil-bearing crops & 3804.8 & 2012.7 & 58911.7 \\
Sugar crops & 34.5 & 15.2 & 444.9 \\
Cotton & 860.1 & 467.0 & 13669.1 \\
Tubers & 3795.2 & 1844.5 & 53988.5 \\
Beans & 5428.0 & 2947.4 & 86270.4 \\
Rice & 2456.1 & 1053.7 & 30841.8 \\
Total & 32862.6 & 16582.5 & 485368.7 \\
\hline
\end{tabular}

it with coal or natural gas, or to run freestanding power stations. At a national level, the UK adopted the National Bioenergy Strategy that aims to promote generation of heat and electricity from biomass resources. Additionally, the UK developed the Energy Crop Scheme that provide farmers with grants for establishing energy crops such as short rotation coppice and miscanthus. Currently, all major coal-fired power plants in UK have adopted biomass co-firing. On average, these plants fire $5 \%-10 \%$ biomass by energy basis. Most plants began their co-firing experience with co-milling trials and then moved on to establish direct injection systems for commercial production. A variety of feedstock has been utilized in UK's coal combusting plants, including: agriculture residues, energy crops and forestry residues. This provides a good model for Kazakhstan to emulate.

2. Green Certificate Policies with bioenergy targets should be applied to the power generation sector. Both dedicated bioenergy and co-generation plants in the UK are in receipt of Renewable Energy Certificates (RECs) and Renewable Obligation Certificates (ROCs). RECs represent a contractual right of the holder to claim any benefit that is associated with energy created from renewable sources. They are sometimes known as "Green Tags" or "Renewable Energy Credits". Each REC certifies that a single megawatt-hour of electricity was generated from renewable sources. The ROCs are green certificates issued to operators of accredited renewable generating stations for the eligible renewable electricity they generate. Operators can trade ROCs with other parties. We propose that Kazakhstan adopt a similar scheme.

3. It is essential to create an effective logistics planning and resource supply chain which incentivises the repurposing of forest, agricultural and livestock wastes for energy generation. According to Sahay (2003), there are three types of supply chain collaboration to enable visibility; firstly, between raw material suppliers; secondly between manufacturers and retailers and thirdly, collaboration between third parties. In bioenergy third party collaboration, partnerships exists in both upstream and downstream sectors of the supply chain. Examples of this type are also seen in the UK bioenergy industry demonstrated by the type of arrangements between forestry providers and CHP production. Supply chain and logistics planning is based at the strategic level in the supply chain. Given the co-location of adequate biomass resources to thermal power plant an improved supply chain is an essential pre-requisite for the transition to a lower carbon economy through biomass cofiring.

\section{Conclusions}

Here we have demonstrated how ArcGIS combined with theoretical energy potential offers decision-makers information on the availability and type of biomass options for Kazakhstan. Biomass co-firing is an attractive option for reducing carbon emissions as it can use existing power plant infrastructure. In this paper, we have identified the main residues available in Kazakhstan for bioenergy production as well as their geographical distribution. The bioenergy potential is estimated about $485.36 \mathrm{MJ}$ (or $16.582 \mathrm{Mt}$ of coal equivalent), which account for about $30 \%$ of total current energy consumption of the country. Wheat residues constitute the major part of Kazakhstan's bioenergy potential, accounting for $44 \%$ of the total bioenergy potential. The results also reveal an imbalance in the spatial distribution of bioenergy resources, driven by climate and topography. The northern and southern provinces of Kazakhstan have the highest bioenergy potential from wheat residues, while the dryland central provinces have the least potential. Aridity, salinization and land degradation ensures that the western provinces are inappropriate for bioenergy production from biomass. The top three provinces with the highest crop biomass energy resources are Akmola, Kostanay, and North Kazakhstani provinces, located in the north of Kazakhstan. Considering the fact that main country's coal-fired power plants are located close to the biomass source regions in the Northern part of Kazakhstan, it is feasible to apply biomass co-firing technologies in this region of Kazakhstan. To ensure the viability of such an initiative some additional work is now required to estimate the: (i) technical energy potential from livestock and forest residues; (ii) logistics of the resource supply chain 
including geographical accessibility, transportation cost and certain radius of the thermal plants; (iii) carbon emission reduction potential under different scenarios on development of bioenergy and policy actions in Kazakhstan; (iv) biomass energy subsidies and costs.

Data availability. The datasets and high-definition maps generated during the current study are available from the corresponding author on reasonable request.

Author contributions. AK and MK conceived and designed the idea of the study. AK and WN collected data, developed and performed the calculations. MLC and MK analyzed the results, wrote and revised the manuscript. AK and MK developed the ArcGIS-Tool and created a map series. All authors discussed the results and contributed to the manuscript.

Competing interests. The authors declare that they have no conflict of interest.

Special issue statement. This article is part of the special issue "European Geosciences Union General Assembly 2018, EGU Division Energy, Resources \& Environment (ERE)". It is a result of the EGU General Assembly 2018, Vienna, Austria, 8-13 April 2018.

Acknowledgements. This research was supported by the British Council Newton Al-Farabi Partnership Programme Grant to Marat Karatayev and Michèle L. Clarke "The potential application of renewable energy for rural energy services and electrification in Kazakhstan". Additional support was provided by Kazakhstani Ministry of Science's Grant AP051310298 "Sustainable development and the water-energy-food nexus in Central Asian region". The authors would like to thank the anonymous reviewers who improved the manuscript and discussions with participants of 2018 European Geosciences Union General Assembly (Division Energy, Resources \& the Environment).

Edited by: Viktor Bruckman

Reviewed by: two anonymous referees

\section{References}

Ahmad, S., Nadeem, A., Akhanova, G., Houghton, T., and Muhammad-Sukki, F.: Multi-criteria evaluation of renewable and nuclear resources for electricity generation in Kazakhstan, Energy, 141, 1880-1891, 2017.

Assembayeva, M., Egerer, J., Mendelevitch, R., and Zhakiyev, N.: A spatial electricity market model for the power system: The Kazakhstan case study, Energy, 149, 762-778, 2018.

Chang, I. S., Wu, J., Zhou, C., Shi, M., and Yang, Y.: A timegeographical approach to biogas potential analysis of China, Renew. Sust. Energ. Rev., 37, 318-333, 2014.
Energy Information Agency (EIA): Country Analysis Brief: Kazakhstan 2017, available at: https://www.eia.gov (last access: 2 May 2018), 2017.

Food and Agriculture Organization of the United Nations (FAO): AQUASTAT - FAO's Information System on Water and Agriculture. Country profile: Kazakhstan 2016, available at: http: //www.fao.org/countryprofiles (last access: 2 May 2018), 2016.

Food and Agriculture Organization of the United Nations (FAO): FAO's Bioenergy and Food Security (BEFS) Rapid Appraisal 2017, available at: http://www.fao.org/energy/bioenergy/befs/ assessment/befs-ra/en/ (last access: 18 June 2018), 2017.

Hiloidhari, M., Das, D., and Baruah, D. C.: Bioenergy potential from crop residue biomass in India, Renew. Sust. Energ. Rev., 32, 504-512, 2014.

Interstate Commission on Sustainable Development (ICSD): National Report on the State of the Environment and Resource use of Kazakhstan 2016, available at: https://www.mkurca.org (last access: 4 August 2018), 2016.

Jiang, D., Zhuang, D., Fu, J., Huang, Y., and Wen, K.: Bioenergy potential from crop residues in China: Availability and distribution, Renew. Sust. Energ. Rev., 16, 1377-1382, 2012.

Kamel, S., El-Sattar, H. A., Vera, D., and Jurado, F.: Bioenergy potential from agriculture residues for energy generation in Egypt, Renew. Sust. Energ. Rev., 94, 28-37, 2018.

Karatayev, M. and Clarke, M. L.: A review of current energy systems and green energy potential in Kazakhstan, Renew. Sust. Energ. Rev., 55, 491-504, 2016.

Karatayev, M., Hall, S., Kalyuzhnova, Y., and Clarke, M. L.: Renewable energy technology uptake in Kazakhstan: Policy drivers and barriers in a transitional economy, Renew. Sust. Energ. Rev., 66, 120-136, 2016.

Karatayev, M., Rivotti, P., Sobral Mourão, Z., Konadu, D. D., Shah, N., and Clarke, M.: The water-energy-food nexus in Kazakhstan: challenges and opportunities, Enrgy. Proced., 125, 63-70, 2017.

Kazakhstan Institute of Geography (KIG): National atlas of Kazakhstan, Environment and natural resources, Almaty, Kazakhstan, 2013.

Kazakhstan's Agency of Statistics (KAS): Agriculture trends 19952016, available at: http://stat.gov.kz/ (last access: 16 February 2018), 2016.

Kazakhstan's Agency of Statistics (KAS): Demographic trends 1991-2016, available at: http://stat.gov.kz/ (last access: 16 February 2018), 2017.

Kazenergy: National Energy Report 2017, available at: http://www. kazenergy.com/ (last access: 4 March 2018), 2017.

KEGOC: Annual report "Kaz Electricity Grid Operating Company", available at: https://www.kegoc.kz (last access: 16 March 2018), 2016.

Kerimray, A., Rojas-Solórzano, L., Torkmahalleh, M. A., Hopke, P. K., and Gallachóir, B. P. Ó.: Coal use for residential heating: Patterns, health implications and lessons learned, Energy Sustain. Dev., 40, 19-30, 2017.

Kerimray, A., Suleimenov, B., De Miglio, R., Rojas-Solórzano, L., Torkmahalleh, M. A., and Gallachóir, B. P. Ó.: Investigating the energy transition to a coal free residential sector in Kazakhstan using a regionally disaggregated energy systems model, J. Clean. Prod., 196, 1532-1548, 2018.

Kukk, L., Roostalu, H., Suuster, E., Rossner, H., Shanskiy, M., and Astover, A.: Reed canary grass biomass yield and energy use ef- 
ficiency in Northern European pedoclimatic conditions, Biomass Bioenerg., 35, 4407-4416, 2011.

Lempp, P.: Biomass Co-Firing in Coal Power Plants. IEAETSAP and IRENA technology policy brief, available at: https://iea-etsap.org/E-TechDS/PDF/E21IR_Bio-cofiring_PL_ Jan2013_final_GSOK.pdf (last access: 13 August 2018), 2013.

Ministry of Energy Republic of Kazakhstan (MoE): Report of the Minister of Energy (K. Bozumbayev) on the Government Hour in the Parliament of Kazakhstan (21.05.2018), available at: http: //energo.gov.kz/, last access: 23 July 2018.

Namsaraev, Z. B., Gotovtsev, P. M., Komova, A. V., and Vasilov, R. G.: Current status and potential of bioenergy in the Russian Federation, Renew. Sust. Energ. Rev., 81, 625-634, 2018.

Noorollahi, Y., Kheirrouz, M., Asl, H. F., Yousefi, H., and Hajinezhad, A.: Biogas production potential from livestock manure in Iran, Renew. Sust. Energ. Rev., 50, 748-754, 2015.

Nyussupova, G. and Kalimurzina, A.: The dynamics of sex-age structure of the population in urban and rural areas in the Republic of Kazakhstan in the years 1991-2013, Bulletin of Geography, 31, 87-111, 2016.

Ramachandra, T. V. and Shruthi, B. V.: Spatial mapping of renewable energy potential. Renew. Sust. Energ. Rev., 11, 1460-1480, 2007.

Roni, M. S., Chowdhury, S., Mamun, S., Marufuzzaman, M., Lein, W., and Johnson, S.: Biomass co-firing technology with policies, challenges, and opportunities: A global review, Renew. Sust. Energ. Rev., 78, 1089-1101, 2017.

Sahay, B. S.: Supply chain collaboration: the key to value creation, Work Study, 52, 76-83, 2003.
Salnikov, V., Turulina, G., Polyakova, S., Petrova, Y., and Skakova, A.: Climate change in Kazakhstan during the past 70 years, Quatern. Int., 358, 77-82, 2015.

Shane, A., Gheewala, S. H., Fungtammasan, B., Silalertruksa, T., Bonnet, S., and Phiri, S.: Bioenergy resource assessment for Zambia, Renew. Sust. Energ. Rev., 53, 93-104, 2016.

Terehovics, E., Khabdullin, A., Khabdullin, A., Khabdullina, Z., Khabdullina, G., Veidenbergs, I., and Blumberga, D.: Why Solar Electricity has High Potential for Kazakhstan Industries, Enrgy. Proced., 113, 417-422, 2017.

Twaha, S., Ramli, M., Murphy, P., Mukhtiar, M., and Nsamba, H.: Renewable based distributed generation in Uganda: resource potential and status of exploitation, Renew. Sust. Energ. Rev., 57, 786-798, 2016.

UNDP Kazakhstan (UNDP): Wind Atlas 2015, available at: http: //atlas.windenergy.kz/ (last access: 16 March 2018), 2015.

UNDP Kazakhstan (UNDP): Solar Resources Atlas 2018, available at: http://atlassolar.kz/, last access: 30 June 2018.

Valdez-Vazquez, I., Acevedo-Benítez, J. A., and HernándezSantiago, C.: Distribution and potential of bioenergy resources from agricultural activities in Mexico, Renew. Sust. Energ. Rev., 14, 2147-2153, 2010.

Water Stress Index (WSI): The World's Most Water-Stressed Countries 2015, available at: http://www.wri.org, last access: 10 July 2018.

Zhuang, D., Jiang, D., Liu, L., and Huang, Y.: Assessment of bioenergy potential on marginal land in China, Renew. Sust. Energ. Rev., 15, 1050-1056, 2011. 